\title{
ODPOWIEDZIALNOŚĆ ZA BLĄD W SZTUCE MEDYCZNEJ W SYSTEMIE PRAWNYM CHIŃSKIEJ REPUBLIKI LUDOWEJ
}

Praktyka medyczna odzwierciedla specyficzną relację między osobami mającymi kwalifikacje do świadczenia pomocy zdrowotnej a pacjentami, dlatego tak ważne jest zachowanie w każdym indywidualnym przypadku podstawowych zasad rozpoznawania chorób i zalecanego sposobu leczenia. Z uwagi na charakter realizowanych zadań w kontekście interesu publicznego wykonywanie zawodu lekarza, pielęgniarki czy położnej łączy się ze szczególną odpowiedzialnością za podejmowane czynności w ramach udzielanych świadczeń zdrowotnych. Przynależność do określonych profesji medycznych jest związana z koniecznością poszanowania obowiązujących norm prawnych, etycznych, obyczajowych itp., które wyznaczaja dopuszczalne granice pomocy medycznej oferowanej przez podmioty profesjonalne. Postawienie błędnej diagnozy lub zastosowanie nieprawidłowej terapii, niezgodnych z zasadami aktualnej wiedzy medycznej, mających ujemne konsekwencje dla życia lub zdrowia pacjenta, jest podstawą do stwierdzenia naruszenia wymaganych reguł ostrożności przez osoby wykonujące zawody medyczne.

Licząca kilka tysięcy lat tradycyjna medycyna chińska, korzystając z akupunktury, akupresury czy ziołolecznictwa, stanowi ważną część dziedzictwa kulturowego Państwa Środka. Postępujące przez wieki osłabienie i izolacja Chin na arenie międzynarodowej przyczyniły się w XIX wieku do podjęcia skutecznych interwencji w tym państwie przez zachodnie mocarstwa, co w rezultacie doprowadziło do coraz częstszych wzajemnych kontaktów między Wschodem i Zachodem. Dzięki temu dokonała się wymiana kulturowa, m.in. w zakresie ekonomii, medycyny, prawa czy technologii. Modernizacja i okcydentalizacja Chin umożliwiły zaadaptowanie w pierwszej połowie XX wieku wielu europejskich rozwiązań w chińskim porządku prawnym, co znalazło swój wyraz w uchwaleniu tzw. sześciu ustaw Kuomintangu (六法全书, Liu fa quan shu), obejmujących zbiór najważniejszych przepisów prawa krajowego: prawo konstytucyjne, prawo cywilne, prawo postępowania cywilnego, prawo karne, prawo postępowania karnego, prawo administracyjne ${ }^{1}$. Właściwa

ORCID: 0000-0002-2700-1578, DOI: 10.4467/23538724GS.20.019.12137

1 Por. V. Behr, Development of a New Legal System in the People's Republic of China, „Lousiana Law Review" 2007, vol. 67, no. 4, s. 1163; A. Kość, Roz̨wój prawa w czasie Republiki Cbińskiej 
regulacja odpowiedzialności za błąd w sztuce medycznej została określona w chińskim prawodawstwie dopiero po śmierci Mao Zedonga.

\section{Polityka zdrowotna w okresie rządów Mao Zedonga}

Analiza zagadnienia odpowiedzialności za błąd w sztuce medycznej w systemie prawnym Chińskiej Republiki Ludowej ukazuje ewolucję stanowiska chińskiego rządu w ciagu ostatnich 30 lat w kierunku takiego uregulowania istniejących rozwiazań, aby harmonizowały różne interesy personelu medycznego i poszkodowanych pacjentów. Po proklamowaniu 1 października 1949 r. ChRL zdecydowano się ufundować nowy porządek na ideologii marksistowsko-leninowskiej, według wzorców radzieckich, w związku czym uchylono obowiązywanie sześciu ustaw Kuomintangu. W okresie 1949-1987 zasady odpowiedzialności za błąd w sztuce medycznej w ChRL nie były w ogóle uregulowane w przepisach prawnych, natomiast jakiekolwiek spory na tym tle rozstrzygano zazwyczaj w sposób niesformalizowany, na drodze administracyjnej ${ }^{2}$. W ówczesnych warunkach wynikało to głównie z przyczyn ideologicznych, gdyż wszystkie decyzje miały być podejmowane zgodnie z obowiązującym kierunkiem polityki partii komunistycznej.

Za rządów Mao Zedonga (1949-1976) dominował nihilizm prawny, przejawiajacy się w arbitralności decyzji władzy oraz petryfikacji systemu prawa. Zgodnie z teorią marksistowską prawo było odbiciem obecnych w społeczeństwie konfliktów klasowych, przepisy miały służyć jedynie ich rozwiązywaniu lub łagodzeniu, jednak wraz z przejściem od socjalizmu do komunizmu jakiekolwiek klasy i konflikty powinny zniknać, zaś samo prawo ostatecznie zastapiłaby moralność ${ }^{3}$. W tym duchu prawo było traktowane w maoistowskich Chinach jako przejściowe zło konieczne, co doprowadziło do odrzucenia potrzeby uchwalenia nowych regulacji prawnych na rzecz centralnego zarządzania państwem przez aparat partyjny za pomocą decyzji administracyjnych. Ustawodawstwo miało bowiem przede wszystkim służyć jako instrument realizacji określonych celów politycznych, nie zaś jako podstawa ochrony praw prywatnych jednostki ${ }^{4}$.

Początkowo pomoc medyczna miała być organizowana na terenie komuny lub miejsca pracy, przy czym warto zaznaczyć, że wszystkie instytucje medyczne należały

(1912-1949) [w:] Chiny w oczach Polakón. Ksiega jubileuszowa z. okazji 60-lecia nawiqzania stosunkón dyplomatycznych miedsy Polska a Chinskeq Republika Ludowa, red. J. Włodarski, K. Zeidler, M. Burdelski, Gdańsk 2010, s. 518; M.P. Gilpatrick, The Status of Law and Lawmaking Procedure Under the Kuomintang 1925-46, „The Far Eastern Quarterly” 1950, vol. 10, no. 1, s. 38-55.

2 Z. Wang, K. Oliphant, Yangge Dance: The Rhythm of Liability for Medical Malpractice in the People's Republic of China, „Chicago-Kent Law Review” 2011, vol. 87, no. 1, s. 26.

3 R. Tokarczyk, Komparatystyka prawnicza, Warszawa 2008, s. 102.

4 P.B. Potter, China's Legal System, Polity Press, Cambridge - Malden 2013, s. 25. 
do sektora publicznego, a podstawowa opieka zdrowotna była bezpłatna ${ }^{5}$. Główne wysiłki władz koncentrowały się na zapewnieniu działań profilaktycznych, włączeniu dorobku zachodniej medycyny do medycyny chińskiej, jak również inicjowaniu masowych kampanii zdrowotnych. W okresie rewolucji kulturalnej (1966-1976) zostały zamknięte uniwersytety i szkoły medyczne, a wykładowców i studentów wysłano do pracy na wsi. Ze względu na pogłębiające się różnice między miastem a wsią w zakresie dostępu do opieki zdrowotnej Mao Zedong ogłosił w 1965 r. rozpoczęcie programu tzw. bosonogich lekarzy, polegającego na zorganizowaniu na obszarach wiejskich osób mających prawo do świadczenia pomocy medycznej dla miejscowej ludności (po ukończeniu jedynie kilkumiesięcznych kursów medycznych), dzięki czemu zapewniono mieszkańcom wsi podstawowe usługi zdrowotne ${ }^{6}$. Oprócz tego, w latach 50. i 70. XX wieku przeprowadzono w Chinach masowe akcje, tzw. patriotyczne kampanie zdrowotne dotyczące najbardziej groźnych chorób, np. błonicy, cholery, duru brzusznego, gruźlicy, malarii, tyfusu, schistosomatozy ${ }^{7}$.

Już w 1953 r. chiński rząd stwierdził przypadki nieprawidłowego funkcjonowania służby zdrowia, które były związane z różnymi poważnymi zaniedbaniami personelu medycznego, co skutkowało zgonami pacjentów lub pogorszeniem stanu ich zdrowia ${ }^{8}$. Nie doprowadziło to jednak do zmiany przepisów prawa w kierunku uwzględnienia w większym stopniu interesów poszkodowanych w wyniku błędów w sztuce medycznej, co zostało dodatkowo potwierdzone w krajowym orzecznictwie. W dniu 18 stycznia 1964 r. Najwyższy Sąd Ludowy (NSL) udzielił odpowiedzi (批复, pi fu) na pytanie prawne, że „w postępowaniu w sprawie wypadków medycznych sąd nie powinien przyznawać rekompensaty finansowej, ale może szukać innych form wyrównania szkody pacjentom, którzy ponieśli śmierć lub doznali kalectwa albo utracili [dotychczasowe - K.G.] dochody na skutek wypadków medycznych"9. Stanowisko to stanowiło aprobatę utrzymywania dotychczasowej linii interpretacyjnej w sprawie błędów w sztuce medycznej. Nadal nie obowiązywały jednolite zasady rozwiązywania tego rodzaju zagadnień, dlatego też podstawowe decyzje mogły zapadać wyłącznie nieformalnie, na szczeblu administracyjnym.

\footnotetext{
5 Z. Wang, K. Oliphant, Yangge Dance..., s. 23.

6 Z. Dong, M.R. Phillips, Evolution of China's health-care system, „The Lancet” 2008, vol. 372(9651), s. 1715; Directive on Public Health, 26 June 1965 [w:] Mao Zedong, Selected Works, vol. 9, Hyderabad 1994, https://www.marxists.org/reference/archive/mao/selected-works/volume-9/index.htm (dostęp: 20.05.2020).

L. Bu, Disseminating Health Knowledge: Public Health Campaigns in 20th-Century China, https:// www.nlm.nih.gov/exhibition/education/chinesepublichealthposters/highereducation/class4. html (dostęp: 18.04.2020).

8 Z. Wang, K. Oliphant, Yangge Dance..., s. 26.

9 Ibidem, s. 27. Odpowiedź Najwyższego Sądu Ludowego z dnia 18 stycznia 1964 r. w sprawie nieprzyznawania rekompensaty finansowej za wypadki medyczne (最高人民法院关于处理医 疗事故案件不应判给经济补偿问题的批复: 1964年1月18日).
} 


\section{Wpływ reform Denga Xiaopinga \\ na chińską politykę zdrowotną}

Zasadnicze zmiany nastapiły dopiero po śmierci Mao, gdy pod kierunkiem Denga Xiaopinga zainicjowano politykę reformy i „otwarcia na świat” (改革开放, gaige kaifang), które przede wszystkim miały dostosować chińską gospodarkę do warunków wolnego rynku, przy wzięciu pod uwagę dynamicznie rozwijającego się sektora prywatnego ${ }^{10}$. Podczas obrad III Plenum Komitetu Centralnego Komunistycznej Partii Chin w dniach 18-22 grudnia 1978 r. oficjalnie zatwierdzono nowy kurs polityki, bazujący m.in. na wprowadzaniu reformy gospodarczej od stycznia 1979 r., wzmocnieniu kolektywnego podejmowania decyzji w partii komunistycznej, ustanowieniu właściwych struktur i regulacji prawnych ${ }^{11}$. Jednym z zasadniczych aspektów Dengowskiego „poszukiwania prawdy w faktach” miało być zaadaptowanie ustawodawstwa do nowych perspektyw rozwoju ekonomicznego ChRL. Kierownictwo partyjne podkreślało, że uchwalenie odpowiednich przepisów prawnych będzie konieczne dla planowanych głębokich przemian społeczno-gospodarczych ${ }^{12}$.

Przeprowadzenie w latach 80. ubiegłego wieku zasadniczych reform w Państwie Środka doprowadziło do znaczącej poprawy sytuacji ekonomicznej i zdrowotnej społeczeństwa, co z kolei miało wpływ na spadek zachorowań na choroby zakaźne, obniżenie śmiertelności niemowląt czy wzrost długowieczności ${ }^{13}$. Uświadomiono sobie, że niezbędne jest również zainicjowanie reformy usług medycznych, która wymagała stworzenia właściwych mechanizmów prawnych, będących podstawą do rozwiązywania sporów między lekarzami a pacjentami ${ }^{14}$. Opieka zdrowotna była nadal finansowana w ChRL z budżetu państwa, przy czym stopniowo następowała prywatyzacja świadczeń medycznych. Obowiązywanie limitów cenowych za dostęp do podstawowej pomocy medycznej skutkowało tym, że niektórzy mieszkańcy coraz częściej zaczęli nabywać droższe farmaceutyki i korzystać z zaawansowanych technologii medycznych, co sprzyjało rozwojowi sektora prywatnego. Z tego względu wiele rodzin nie miało środków na sfinansowanie opieki lekarskiej, jak też objęcia ich zakresem ochrony ubezpieczeniowej ${ }^{15}$.

Godna uwagi jest okoliczność, że wobec braku właściwych przepisów prawnych często przypadki błędów w sztuce medycznej kwalifikowano na gruncie prawa kar-

10 M. Walkowski, Chiński model rozwoju spoteczno-gospodarczego i jego potencjalna adaptacja w Europie, „Przegląd Strategiczny” 2017, nr 10, s. 337.

11 M. Dillon, Deng Xiaoping: The Man who Made Modern China, New York 2015, s. 245.

12 J. Chen, Chinese Law: Towards an Understanding of Chinese Law, Its Nature and Development, Hague - London - Boston 1999, s. 40.

13 Z. Dong, M.R. Phillips, Evolution..., s. 1715.

14 Z. Wang, K. Oliphant, Yangge Dance..., s. 27.

15 Z. Dong, M.R. Phillips, Evolution..., s. 1715, 1716. 
nego jako zupełnie inne przestępstwo, np. spowodowanie śmierci w wyniku niedbalstwa, poważny wypadek z powodu niedbalstwa, zaniedbanie obowiązków. Taka praktyka budziła wątpliwości, ponieważ błąd w sztuce medycznej nie był wówczas stypizowany w kodeksie karnym z dnia 1 lipca 1979 r. jako odrębny czyn zabroniony, natomiast przyporządkowano go do znamion innych przestępstw ${ }^{16}$. W $1997 \mathrm{r}$. wprowadzono do kodeksu karnego Chińskiej Republiki Ludowej z dnia 1 lipca 1979 r. (ze zm.) nowy art. 335, który dotyczy błędu w sztuce medycznej, skutkującego śmiercią lub poważnym uszczerbkiem na zdrowiu pacjenta: „Pracownik medyczny, który rażąco narusza swoje obowiązki, powoduje śmierć lub poważny uszczerbek na zdrowiu osoby starającej się o opiekę medyczna, podlega karze pozbawienia wolności na okres do lat 3 albo karze aresztu" ${ }^{17}$. Warto dodać, że chińska procedura karna przewiduje możliwość złożenia przez pokrzywdzonego w toku postępowania karnego powództwa cywilnego, dzięki czemu ma on prawo dochodzić roszczeń majątkowych wynikających z przestępstwa ${ }^{18}$.

\section{Odpowiedzialność prawna za błąd w sztuce medycznej: reżim administracyjny}

\section{Zasady postępowania w sprawie wypadków medycznych z dnia 29 czerwca 1987 r.}

Ogólnochińskie Zgromadzenie Przedstawicieli Ludowych uchwaliło 12 kwietnia 1986 r. tzw. Ogólne zasady prawa cywilnego (OZPC, 民法通则), które zaczęły obowiązywać od 1 stycznia 1987 r. ${ }^{19}$ Zamiarem chińskich władz było jednak wyłączenie stosowania przepisów prawa cywilnego w stosunku do wypadków medycznych, aby tego rodzaju sprawy mogły być rozpatrywane wyłącznie przez organy administracji. W 1985 r. lokalne przepisy prawa administracyjnego uchwalono w Szanghaju i prowincji Shanxi, natomiast Rada Państwa ChRL 29 czerwca 1987 r. ogłosiła Zasady postępowania w sprawie wypadków medycznych (医疗事故处理

16 Z. Wang, K. Oliphant, Yangge Dance..., s. 27.

17 https://www.ilo.org/dyn/natlex/docs/ELECTRONIC/5375/108071/F-78796243/ CHN5375\%2520Eng3.pdf (dostęp: 19.04.2020).

18 Artykuł 36 kodeksu karnego ChRL stanowi: „If a victim suffers economic losses as a result of a crime, the criminal shall, in addition to receiving a criminal punishment according to law, be sentenced to compensation for the economic losses in the light of the circumstances".

19 中华人民共和国民法通则: 2009年修正), http://www.npc.gov.cn/zgrdw/npc/lfzt/rlys/ 2014-10/28/content_1883354.htm (dostęp: 20.04.2020). Należy podkreślić, że w dniu 15 marca 2017 r. chiński parlament uchwalił Ogólne przepisy prawa cywilnego, tym samym wprowadzając istotne zmiany w dotychczas obowiązujących przepisach cywilnych. Nowe przepisy weszły w życie 1 października 2017 r. 
办法, Yiliao Shigu Chuli Banfa, dalej: ZPWM ${ }^{20}$. Tego typu rozwiazanie doprowadziło do ograniczenia okoliczności warunkujących powstanie odpowiedzialności za błąd w sztuce medycznej, ponieważ roszczenia pacjentów w okresie 1987-2009 mogły być formalnie dochodzone na podstawie przepisów prawa administracyjnego. Dopiero pod koniec lat 80. problematyka odpowiedzialności prawnej za popełnione błędy w sztuce medycznej stała się przedmiotem uwagi władz ChRL ${ }^{21}$. W ten sposób po raz pierwszy wprowadzono w Chinach sformalizowane procedury odpowiedzialności administracyjnej dotyczące wypadków medycznych.

Relacje między instytucjami medycznymi a pacjentami miały zatem w ówczesnych warunkach raczej charakter quasi-administracyjny, a nie prywatnoprawny ${ }^{22}$. Chińskie władze zdecydowały, że pacjenci maja przede wszystkim występować z roszczeniami do organów administracji medycznej, przy pominięciu krajowego wymiaru sprawiedliwości, co budziło wątpliwości z uwagi na postępująca prywatyzację usług medycznych. Wiele poszkodowanych osób zaczęło jednak wnosić powództwa za uszczerbek na zdrowiu, wynikający z błędów personelu medycznego, na podstawie Ogólnych zasad prawa cywilnego z 1986 r., a nie Zasad postępowania w sprawie wypadków medycznych z 1987 r. Praktyka ta została wkrótce zaakceptowana przez niektóre sądy krajowe. Przypadki błędów lekarskich mogły być kwalifikowane na gruncie przepisów prawa cywilnego jako zwykłe niedbalstwo, a nie trudniejsze do udowodnienia wypadki medyczne, które są regulowane w przepisach prawa administracyjnego. W rezultacie doszło do ukształtowania się w Chinach dwóch reżimów prawnych (administracyjnego i cywilnego) w zakresie odpowiedzialności za błąd w sztuce medycznej. Istniejąca dychotomia legislacyjna prowadziła do sytuacji, że roszczenie za błąd w sztuce medycznej mogło być oparte na dwóch różnych podstawach prawnych. W przeciwieństwie do OZPC, przepisy z 1987 r. przewidywały poważne ograniczenia, ponieważ pacjentom formalnie nie przyznano prawa do odszkodowania i zadośćuczynienia za szkodę medyczna, mogli jedynie wystapić o przyznanie tzw. dodatku ryczałtowego (bu chang, 补偿; ang. lump sum allowance), wypłacanego przez instytucję medyczna (art. 18 ZPWM).

Dzięki uchwaleniu nowej regulacji administracyjnej z 1987 r. stworzono formalne podstawy dochodzenia przez osoby poszkodowane roszczeń z tytułu błędu w sztuce medycznej, które miały mieć formę dodatku ryczałtowego. Lekarze i szpitale ponosili odpowiedzialność administracyjną za szkodę pacjenta, będącą

20 医疗事故处理办法, http://www.nhc.gov.cn/yzygj/s3576/200804/f62b22b1047f4f699c9 0733b8012a4ff.shtml (dostęp: 20.04.2020).

21 Z. Wang, K. Oliphant, Yangge Dance..., s. 28, 29.

22 D.M. Harris, Chien-Chang Wu, Medical malpractice in the People's Republic of China: The 2002 regulation of the handling of medical accidents, „Journal of Law, Medicine and Ethics” 2005, vol. 33, s. 456. 
skutkiem postępowania sprzecznego z uznanymi zasadami wiedzy medycznej ${ }^{23}$. Według poglądów doktryny wynikająca $z$ nowych przepisów konstrukcja prawna odpowiedzialności nie korespondowała ściśle z żadną ze znanych teorii winy w zakresie odpowiedzialności cywilnej ${ }^{24}$. Pacjentom należało częściowo zapewnić zwrot kosztów opieki zdrowotnej i innych wydatków, z wyjątkiem kosztów utrzymania, które miały zostać pokryte z budżetu rządu, przedsiębiorstwa spółdzielczego lub pracodawcy ${ }^{25}$. Przyznanie dodatku ryczałtowego miało charakter jednorazowej wypłaty dla pacjenta, nie pełniąc właściwej funkcji kompensacyjnej (takiej jak odszkodowanie i zadośćuczynienie), było udzielane wyłącznie w razie ujawnienia wypadku medycznego z powodu niedbalstwa, natomiast nie odnosiło się do samych wypadków technicznych, przez co uniemożliwiono wielu pacjentom dochodzenie roszczeń z powodu różnych błędów w sztuce medycznej ${ }^{26}$. Wysokość dodatku zależała od wystąienia trzech elementów: stopnia ciężkości wypadku medycznego (ocenianego w skali 1-3), okoliczności zdarzenia oraz dotychczasowego stanu zdrowia pacjenta. Kwoty, jakie przyznawano osobom poszkodowanym, były stosunkowo niskie, nie stanowiąc rzeczywistego ekwiwalentu $z$ tytułu poniesionej szkody ${ }^{27}$.

Zgodnie $\mathrm{z}$ art. 2 ZPWM podstawą dochodzenia roszczeń $\mathrm{z}$ tytułu błędu w sztuce medycznej było wystapienie wypadku medycznego, oznaczającego zdarzenie prowadzące do dysfunkcji organizmu, powodujące śmierć, kalectwo lub upośledzenie czynności narządu pacjenta, wynikające z niedbalstwa personelu medycznego w zakresie czynności diagnostycznych, terapeutycznych lub opieki. Wprowadzono podział wypadków medycznych na dwie podstawowe kategorie: wypadki z powodu niedbalstwa albo wypadki techniczne. Wypadki z powodu niedbalstwa odnoszą się do zdarzeń wywołanych postępowaniem personelu medycznego, wynikającym z naruszenia zasad, przepisów, procedur diagnostycznych i leczniczych itp., natomiast wypadki techniczne obejmuja zdarzenia spowodowane przez personel medyczny ze względu na nieprawidłowe leczenie, ale niezwiązane z naruszeniem przepisów lub procedur (art. 5 ZPWM).

Postępowanie administracyjne w sprawie wypadków medycznych, według przepisów z 1987 r., zostało oparte na tzw. procedurze identyfikacji technicznej. W razie wystąpienia okoliczności spornych pacjent, członkowie jego rodziny lub instytucja

23 J. Kearney, Why China's 2010 Medical Malpractice Reform Fails to Reform Medical Malpractice, „Emory International Law Review” 2012, vol. 26, no. 2, s. 1055; https://law.emory.edu/eilr/_documents/volumes/26/2/comments/kearney.pdf (dostęp: 18.05.2020).

$24 \mathrm{X}$. Zhao, The Duty of Medical Practitioners and CAM/TCM Practitioners to Inform Competent Adult Patients about Alternatives, Berlin - Heidelberg 2013, s. 399.

25 D.M. Harris, Chien-Chang Wu, Medical malpractice..., s. 461.

26 Por. N. Lin, W. Hu, The Evolving Legal Mechanism for Medical Malpractice Dispute Resolution in China, „Columbia Journal of Asian Law” 2018, vol. 32(37), s. 50-52.

27 Z. Wang, K. Oliphant, Yangge Dance..., s. 31. 
medyczna musieli skierować wniosek do organu lokalnej administracji zdrowia, następnie okoliczności sprawy były poddawane analizie przez panel ekspertów, tzw. Komitet ds. Oceny Technicznej Wypadków Medycznych (dalej: komitet oceniający). W ówczesnym czasie miał on wyłączne uprawnienie do przeprowadzenia oceny wypadków medycznych w ChRL, a wydana przez niego ocena stanowiła podstawę ustaleń w tego rodzaju postępowaniach. Eksperci wchodzący w skład komitetu oceniającego byli wyznaczani przez właściwy departament ds. zdrowia, funkcjonujący na szczeblu danej prowincji, regionu lub gminy, przy czym nominacja wymagała dodatkowego zatwierdzenia władz lokalnych. Zadaniem komitetu oceniającego było ustalenie dwóch kwestii, tj. czy miał miejsce wypadek medyczny oraz czy istniał bezpośredni związek przyczynowy między wypadkiem medycznym a szkoda pacjenta ${ }^{28}$. Jeżeli pacjent, członek jego rodziny lub instytucja medyczna nie zgadzały się z wydaną decyzją, to mogły w terminie 15 dni od jej otrzymania złożyć wniosek o ponowną ocenę albo wniosek o ponowne rozpatrzenie sprawy. Sprawa mogła zostać skierowana do komitetu oceniającego wyższego stopnia albo po złożeniu pozwu - bezpośrednio do sądu stosującego przepisy z 1987 r. (art. 11 ZPWM). Stanowisko komitetu było nadal istotne przy rozpatrywaniu okoliczności w postępowaniu sądowym, miało de facto charakter wiążący dla sądu ${ }^{29}$.

Opisywany reżim administracyjny w zakresie możliwości dochodzenia roszczeń z tytułu błędów w sztuce medycznej, funkcjonujący w ChRL w latach 1987-2002 miał poważne ograniczenia ${ }^{30}$. Po pierwsze, osoby wchodzące w skład panelu ekspertów (komitetu oceniającego) były nominowane przez lokalny departament zdrowia, co budziło watpliwości w kwestii obiektywizmu, rzetelności, wiarygodności dokonanej oceny. Działalność szpitali (instytucji w większości publicznych) miała być oceniana przez komitet uprzednio wybrany przez organ administracji medycznej, czyli generowało to niepotrzebny konflikt interesów. Ciężar udowodnienia, że wypadek medyczny miał miejsce, spoczywał na pacjencie, który musiał wystapić do odpowiedniej instytucji medycznej o udostępnienie dokumentacji zdrowotnej. Wprawdzie instytucje medyczne były zobowiązane do wyznaczenia osoby odpowiedzialnej za właściwe przechowywanie dokumentacji na temat zdrowia pacjentów, jednak ze względu na brak odpowiednich procedur takie materiały mogły łatwo zostać zniszczone lub ukryte ${ }^{31}$.

28 Ibidem, s. 30; R. McGivern Rossner, Medical Liability and the Doctor-Patient Relationship in China, Report for China Medical Board, s. 12-13; https://chinamedicalboard.org/sites/default/files/ rossner30sept13.pdf (dostęp: 20.04.2020); N. Lin, W. Hu, The Evolving Legal Mechanism..., s. 50.

29 Z. Wang, K. Oliphant, Yangge Dance..., s. 30.

30 D.M. Harris, Chien-Chang Wu, Medical Malpractice..., s. 456.

31 R. McGivern Rossner, Medical Liability..., s. 13, 14. 
2. Zasady postępowania w sprawie

wypadków medycznych z dnia 4 kwietnia 2002 r.

Nowe przepisy regulujące odpowiedzialność za wypadki medyczne zostały ogłoszone przez Radę Państwa ChRL w dniu 4 kwietnia 2002 r. - Zasady postępowania w sprawie wypadków medycznych (医疗事故处理条例, Yiliao Shigu Chuli Tiaoli, dalej: ZPWM z 2002 r.) i weszły w życie 1 września 2002 r. $^{32}$ Wprowadzenie powyższej regulacji było związane z krytyką poprzednich rozwiązań prawnych z 1987 r., które nie uwzględniały w należytym stopniu interesów osób poszkodowanych w wyniku błędów w sztuce medycznej, znacząco ograniczając zakres odpowiedzialności instytucji medycznych ${ }^{33}$. W swoich ogólnych założeniach, zarówno w brzmieniu przepisów z 1987 r., jak i z 2002 r., system dochodzenia roszczeń za błędy w sztuce medycznej był podobny, gdyż podstawowa procedura sprowadzała się do ustalenia, czy dane zdarzenie odpowiada przesłankom wypadku medycznego, jednocześnie przy zachowaniu trybu administracyjnego rozwiązywania sporów ${ }^{34}$. Postępująca reforma służby zdrowia powinna być odczytywana jako kontynuacja transformacji gospodarczej, która skierowała ChRL na drogę dynamicznego rozwoju, w wyniku czego pacjenci przestali być traktowani jako beneficjenci pomocy socjalnej, a stali się przede wszystkim konsumentami usług zdrowotnych ${ }^{35}$. Wprowadzenie istotnych zmian legislacyjnych było konieczne, aby zaadaptować krajowy system służby zdrowia do nowych warunków rynkowych i rozwoju technologii medycznych.

Chiński rząd zdecydował się pozostać przy dotychczasowym reżimie administracyjnym w zakresie odpowiedzialności za błąd w sztuce medycznej, zarazem rozszerzając przesłanki warunkujące prawo pacjentów do otrzymania właściwej rekompensaty pieniężnej. Zasady postępowania z 2002 r. powinno się odczytywać w kontekście postępującej prywatyzacji usług zdrowotnych w Chinach, gdy równocześnie uznano prawo pacjentów do odszkodowania i zadośćuczynienia (赔偿, pei chang, ang. compensation) za szkodę medyczną ${ }^{36}$. Zdecydowano się poszerzyć zakres

32 医疗事故处理条例, http://www.gov.cn/gongbao/content/2002/content_61445.htm (dostęp: 22.04.2020).

33 Z. Wang, K. Oliphant, Yangge Dance..., s. 31, 32.

34 Ibidem, s. 58.

35 N. Lin, W. Hu, The Evolving Legal Mechanism..., s. 50. Zasadnicza zmiana podejścia w kwestii usług zdrowotnych w ChRL znalazła swoje odzwierciedlenie w przepisach, np. art. 34 „Opłaty identyfikacyjne mogą być pobierane za przeprowadzenie identyfikacji technicznej wypadków medycznych. Jeżeli wypadek medyczny zostanie ustalony w chwili przeprowadzenia identyfikacji, zainteresowana instytucja medyczna uiści opłaty identyfikacyjne; jeżeli nie jest to wypadek medyczny, wnioskodawca zajmujący się wypadkiem medycznym uiszcza opłaty identyfikacyjne".

36 Wcześniej przyjęto ustawę o ochronie praw i interesów konsumentów z 1993 r., ogłoszoną w dniu 31 października 1993 r. (消费者权益保护法), oraz ustawę o państwowych świadczeniach odszkodowawczych z dnia 12 maja 1994 r. (国家赔偿法). 
dotychczasowej odpowiedzialności lekarzy i szpitali za błąd w sztuce medycznej. W przeciwieństwie do poprzedniego stanu prawnego szkoda została powiązana z jakimkolwiek uszczerbkiem na zdrowiu, spowodowanym niedbalstwem przy wykonywaniu czynności medycznych, nie zaś jedynie przypadkami śmierci, kalectwa lub upośledzenia czynności narządów. Postępowanie dowodowe uproszczono, gdyż wystarczające było udowodnienie istnienia pośredniego związku przyczynowego między zdarzeniem a szkodą ${ }^{37}$.

Zgodnie z nową definicja wypadek medyczny oznaczał zdarzenie spowodowane przez instytucję medyczną lub jej personel podczas wykonywania czynności medycznych, w wyniku naruszenia przepisów ustawowych, administracyjnych, dotyczących zdrowia i administracji medycznej, standardów i procedur w zakresie diagnozowania, leczenia i pielęgnacji, powodujące uszczerbek na zdrowiu pacjenta $(\text { art. } 2)^{38}$. Zrezygnowano z podziału wypadków medycznych na wypadki z powodu niedbalstwa oraz wypadki techniczne, ale w zależności od stopnia ciężkości uszczerbku wyodrębniono cztery kategorie wypadków medycznych (art. 4) ${ }^{39}$. Instytucja medyczna ponosiła odpowiedzialność jedynie za działanie lekarza, ale już nie za jego zaniechanie skutkujące szkodą pacjenta, przez co zawężono faktyczna możliwość uzyskania rekompensaty pieniężnej ${ }^{40}$. Ponadto instytucje medyczne zostały zobowiązane do sporządzania i prowadzenia na bieżąco dokumentacji medycznej, zgodnie z wymogami określonymi przez departament administracji zdrowia Rady Państwa (art. 8).

Jeżeli dane zdarzenie zostanie zakwalifikowane jako wypadek medyczny, obie strony postępowania mogą drogą wzajemnych konsultacji, rozstrzygać zaistniałe spory dotyczące odpowiedzialności cywilnej za wypadki medyczne. W przeciwnym razie moga złożyć wniosek o mediację do departamentu administracji zdrowia albo bezpośrednio pozew do sądu (art. 46). Departament może na wniosek obu stron przeprowadzić również mediację w zakresie odszkodowania i zadośćuczynienia za wypadek medyczny (art. 48). Przy ustaleniu wysokości rekompensaty z tytułu wypadku medycznego należało wziąć pod uwagę trzy podstawowe czynniki: stopień ciężkości wypadku medycznego, winę personelu medycznego za doznane obrażenia pacjenta w wyniku wypadku, związek między obrażeniami pacjenta w wyniku wypadku medycznego a poprzednią chorobą pacjenta (art. 49).

37 Z. Wang, K. Oliphant, Yangge Dance..., s. 32.

38 Tu i dalej w tej części artykułu przywołane w nawiasie kolejne przepisy dotyczą Zasad postępowania w sprawie wypadków medycznych z $2002 \mathrm{r}$.

39 ZPWM z 2002 r. wyróżniły cztery następujące kategorie wypadków medycznych: 1) skutkujące śmiercią lub ciężką niepełnosprawnością pacjenta; 2) skutkujące średnią niepełnosprawnością lub uszkodzeniem narządu lub tkanki, prowadzące do poważnej dysfunkcji; 3) skutkujące niewielką niepełnosprawnością lub uszkodzeniem narządu lub tkanki, powodujące częstą dysfunkcję; 4) skutkujące innym dostrzegalnym uszczerbkiem u pacjenta.

${ }^{40}$ J. Kearney, Why China's 2010..., s. 1057. 
Kwota przyznanej rekompensaty powinna być obliczona zgodnie z przyjętymi standardami, przy uwzględnieniu rozmiaru poniesionych strat, obejmujących: koszty leczenia, rekompensatę za utratę dochodu pacjenta, dodatek żywieniowy na hospitalizację, koszty opieki nad pacjentem, zasiłek na utrzymanie dla osób niepełnosprawnych, zasiłek inwalidzki, koszty pogrzebu, koszty na wsparcie osób pozostających na utrzymaniu zmarłego przed jego śmiercią lub przez osobę niepełnosprawna przed utrata pracy, dodatek drogowy, dodatek żywieniowy, zadośćuczynienie za doznaną krzywdę (art. 50). W porównaniu z poprzednio obowiązującym stanem prawnym większą wage przywiązano do kwestii szkody pacjenta poprzez kazuistyczne określenie kosztów składających się na łączną kwotę odszkodowania i zadośćuczynienia.

Każda instytucja medyczna była zobowiązana do zgłoszenia wypadków medycznych do lokalnego departamentu administracji zdrowia, natomiast $\mathrm{w}$ razie ujawnienia poważnych błędów (np. zdarzenie mogące być kwalifikowane jako wypadek medyczny I lub II stopnia, spowodowanie uszczerbku u trzech lub więcej pacjentów, inne okoliczności określone przez administrację zdrowia) powinna dokonać zgłoszenia w ciagu 12 godzin (art. 14). Według przepisów z 2002 r. procedura „identyfikacji technicznej” została zmodyfikowana w taki sposób, że w przypadku zgłoszenia poważnych błędów przy wykonywaniu czynności medycznych lub wniosku o rozwiązanie sporu dotyczącego wypadku medycznego departament administracji zdrowia musiał zwrócić się do stowarzyszenia medycznego w celu dokonania uwierzytelnienia technicznego wypadku medycznego (art. 20).

Zorganizowanie procedury „identyfikacji technicznej” dotyczącej wypadków medycznych powierzono stowarzyszeniu medycznemu, w założeniu instytucji niezależnej, co miało gwarantować obiektywizm i rzetelność postępowania. W tym celu instytucja medyczna i pacjent mieli dokonywać losowego wyboru ekspertów mających wiedzę z określonych dziedzin medycyny, a nad prawidłowym przebiegiem procedury czuwało stowarzyszenie medyczne (art. 24). Lokalne stowarzyszenia medyczne, które działają w dzielnicach lub powiatach podlegających bezpośredniej jurysdykcji prowincji, regionów autonomicznych lub gmin, są odpowiedzialne za dokonanie wstępnego uwierzytelnienia wypadków medycznych, natomiast stowarzyszenia medyczne prowincji, regionów autonomicznych lub gmin podlegających bezpośrednio rządowi centralnemu są odpowiedzialne za dalsze uwierzytelnienia (art. 21).

Po otrzymaniu powiadomienia od stowarzyszenia medycznego zainteresowane strony muszą w ciagu 10 dni złożyć dokumenty dotyczące identyfikacji wypadku medycznego, jak również oświadczenia pisemne i argumenty (art. 28). Przekazanie powyższych materiałów pozwala rozpocząć kolejny etap procedury, polegający na zorganizowaniu w ciagu 45 dni postępowania identyfikacyjnego (art. 29). Powołane wcześniej grupy ekspertów muszą przeprowadzić dokładna analizę przekazanych materiałów, oświadczeń pisemnych i argumentów, dokonująi identyfikacji oraz wydają sprawozdanie dotyczące identyfikacji technicznej wypadku medycznego (art. 30). 
Po zmianie przepisów odpowiedzialność za zorganizowanie procedury identyfikacji ponosiły lokalne stowarzyszenia medyczne, jednak w powszechnej opinii rozwiązanie to postrzegano jako faworyzujące instytucje medyczne $z$ uwagi na bliskie nieformalne powiązania członków stowarzyszeń medycznych z organami administracji zdrowia. Oceniano, że procedura identyfikacji technicznej została zrekonstruowana tylko pozornie, nadal zapewniając ochronę interesów członkom środowiska lekarskiego poprzez osłabienie możliwości dochodzenia przez pacjentów roszczeń od instytucji medycznych ${ }^{41}$.

\section{Dychotomia legislacyjna w zakresie odpowiedzialności za błąd w sztuce medycznej w latach 2002-2010}

Uchwalenie przepisów z 2002 r. pogłębiło problem jednoczesnego obowiązywania w ChRL dwóch odrębnych systemów odpowiedzialności - cywilnej i administracyjnej - za doznanie uszczerbku na zdrowiu. Generalnie, jeżeli w wyniku niedbalstwa lekarza pacjent dozna jakichkolwiek obrażeń, dochodzi do naruszenia prawa jednostki do życia i zdrowia, a więc $\mathrm{w}$ takich okolicznościach poszkodowany ma prawo żądać odpowiedniej rekompensaty pieniężnej za uszczerbek na zdrowiu i krzywdę psychiczna. W dniu 12 kwietnia 1986 r. uchwalono OZPC, które weszły w życie 1 stycznia 1987 r. Stanowią one podstawową regulację w dziedzinie stosunków cywilnoprawnych, w tym odpowiedzialności deliktowej. Równolegle, Zasady postępowania w sprawie wypadków medycznych z dnia 4 kwietnia 2002 r., obowiązujące od 1 września 2002 r., określają podstawowe reguły w dziedzinie odpowiedzialności administracyjnej za wypadki medyczne $e^{42}$.

Problematyczny jest brak spójności między oboma powyższymi aktami prawnymi, co odzwierciedla się w różnych rozwiązaniach dotyczących odpowiedzialności za szkodę medyczna. Ze względu na zupełnie odmienne zasady dochodzenia rekompensaty pieniężnej zastosowanie przepisów prawa cywilnego było korzystniejsze dla pacjentów, natomiast odwołanie się do przepisów prawa administracyjnego dla szpitali i lekarzy. OZPC wymaga od lekarzy jako podmiotów profesjonalnych zachowania należytej staranności, a także doświadczenia, umiejętności i wiedzy. Z kolei regulacja prawna z 2002 r. znacząco ogranicza ów standard w taki sposób,

${ }^{41}$ Z. Wang, K. Oliphant, Yangge Dance..., s. 33; B.L. Leibman, Law in the Shadow of Violence: Can Law Help to Improve Doctor-Patient Trust in China?, „Columbia Journal of Asian Law” 2016, vol. 30, no. 1, s. 116, 117; idem, Essay: Malpractice Mobs: Medical Dispute Resolution in China, „Columbia Law Review" 2013, vol. 113, no. 181, s. 13, 14.

42 X. Zhao, Chinese Medical Negligence Law: How to Distinguish and Accommodate Common Law Principles? [w:] Towards a Chinese Civil Code Comparative and Historical Perspectives, eds. L. Chen, C.H. (Remco) van Rhee, Leiden - Boston 2012, s. 409-411. 
że wszelkie zdarzenia wywołane innymi czynnikami niż naruszenie przepisów ustawowych, administracyjnych, dotyczących zdrowia i administracji medycznej, standardów i procedur w zakresie diagnozowania, leczenia i pielęgnacji nie mieszczą się w kategorii „wypadki medyczne"43.

Obie wskazane regulacje przewidują ponadto zupełnie odmienne limity kwotowe oraz zasady dotyczące wysokości odszkodowania i zadośćuczynienia. Proponowana wysokość odszkodowania i zadośćuczynienia za błędy w sztuce medycznej (wypadek medyczny) była znacznie niższa niż porównywalnie w innych sprawach deliktowych (zwykłe niedbalstwo). Za poważny mankament należy uznać fakt, że przepisy prawa administracyjnego nie przewidywały możliwości przyznania rekompensaty finansowej w razie śmierci pacjenta w wyniku wypadku medycznego. Z kolei Sąd Najwyższy przyjął, że w każdym przypadku zwykłego niedbalstwa skutkującego śmiercią poszkodowanego należy się na podstawie przepisów prawa cywilnego wypłata odszkodowania i zadośćuczynienia. W rezultacie, jeżeli powód występuje z takim roszczeniem na drodze administracyjnej, to zazwyczaj otrzymuje rekompensatę niższą o kilkaset tysięcy juanów niż wówczas, gdy występuje z powództwem do sądu ${ }^{44}$. Paradoksalnie, mogłoby dojść do sytuacji, gdy wysokość rekompensaty będzie wyższa w razie ujawnienia mniej poważnych zdarzeń (czyli zwykłego niedbalstwa), które nie mogą zostać zakwalifikowane jako wypadki medyczne. W reżimie administracyjnym to komisje lekarskie, powołane przez lokalne stowarzyszenia medyczne, były odpowiedzialne za ustalenie stanu faktycznego i ocenę wypadku medycznego, czyli zasadniczo nie badano tego w postępowaniu sądowym. Członkami komisji byli wyłącznie lekarze mający praktykę na danym obszarze, a lokalne stowarzyszenia medyczne podlegały kontroli miejscowych departamentów administracji zdrowia, dlatego też mogło dochodzić do poważnego konfliktu interesów w sprawach o szkody medyczne ${ }^{45}$.

Wattpliwości co do tego, czy przepisy z 2002 r. są zgodne z Ogólnymi zasadami prawa cywilnego (OZPC) stały się przedmiotem bliższej uwagi NSL, który w 2003 r. wydał wytyczne dotyczące stosowania przepisów prawa w sprawach o odszkodowanie i zadośćuczynienie za szkodę na osobie. W oparciu o te wytyczne dokonał rozróżnienia między wypadkami medycznymi i wypadkami niemedycznymi, podlegającymi odrębnym reżimom prawnym, utrwalając tym samym istniejąca dychotomię przepisów ${ }^{46}$. Według przyjętej interpretacji w sprawach o odszkodowanie i zadośćuczynienie za wypadek medyczny, który miał miejsce po wejściu w życie

43 N. Lin, W. Hu, The Evolving Legal Mechanism..., s. 51.

44 J. Kearney, Why China's 2010..., s. 1058, 1059; B.L. Leibman, Essay: Malpractice Mobs..., s. 195.

45 Por. B.L. Leibman, Essay: Malpractice Mobs..., s. 194, 195; W. Zheng, Understanding the law of torts in China: A political economy perspective, „University of Pennsylvania Asian Law Review” 2017, vol. 11, no. 2, s. 220.

46 X. Zhao, Chinese Medical Negligence Law...; Renmin Fayuan Guanyu Shenli Renshen Sunhai Peichang Anjian Shiyong Falü Ruogan Wenti De Jieshi (Interpretacja Najwyższego Sądu 
przepisów z 2002 r. (czyli od 1 września 2002 r.), stosuje się odpowiednie przepisy prawa administracyjnego, natomiast w sprawach o odszkodowanie i zadośćuczynienie za uszczerbek na zdrowiu spowodowane innymi przyczynami stosuje się przepisy prawa cywilnego 47 .

Brak transparentności w kwestii dochodzenia odszkodowania i zadośćuczynienia za błąd w sztuce medycznej doprowadził do tego, że wielu pacjentów zaczęło występować z pozwami do sądów przeciwko instytucjom medycznym. Jako podstawę dochodzenia roszczeń wskazywali jednak zwykłe niedbalstwo, nie zaś wypadek medyczny, czyniąc to niejako w celu zobligowania sądów do stosowania OZPC z 1986 r. zamiast mniej korzystnych przepisów prawa administracyjnego z 2002 r. Dzięki temu postępowanie między stronami mogło toczyć się przed sądem, jednocześnie przy wyeliminowaniu możliwego wpływu organów administracji medycznej na rozstrzygnięcie w sprawie ${ }^{48}$. Tego rodzaju praktyka została zaakceptowana przez sądy, które stopniowo dopuściły prawo pacjentów do występowania z pozwem przeciwko instytucjom medycznym, w których doszło do niedbalstwa personelu, skutkującego uszczerbkiem na zdrowiu pacjenta ${ }^{49}$.

Należy uznać, że kilka interpretacji Najwyższego Sądu Ludowego z lat 20022003 dotyczących stosowania prawa w sprawach o odszkodowanie i zadośćuczynienie za szkodę na osobie odegrało rudymentarną rolę w ukształtowaniu się dwóch systemów dotyczących odpowiedzialności za uszczerbek na zdrowiu pacjenta. Powyższe wytyczne były w ówczesnych warunkach niezbędne, aby wyjaśnić wątpliwości prawne, ale jednocześnie stały się podstawą do ugruntowania dwóch systemów dochodzenia odszkodowania i zadośćuczynienia za błędy w sztuce medycznej ${ }^{50}$. NSL zaproponował nową interpretację przepisów prawa cywilnego, która doprowadziła do zmiany rozkładu ciężaru dowodu poprzez odstępstwo od generalnej zasady, że ciężar udowodnienia winy spoczywa zazwyczaj na powodzie. W sprawach deliktowych dotyczących działalności medycznej to na instytucjach medycznych spoczywał ciężar udowodnienia braku związku przyczynowego między zachowaniem lekarza a szkodą oraz braku winy medycznej. Tym samym zaakceptowano odwrócenie ciężaru dowodowego w sprawach dotyczących tzw. winy medycznej (medical fault), które są objęte zakresem stosowania OZPC. Strona pozwana została zobligowana do przedstawienia dowodów, które pozwoliłyby obalić powyższe do-

Ludowego ws. niektórych zagadnień dotyczących stosowania prawa przy badaniu spraw odszkodowawczych za szkodę na osobie, ogłoszona w dniu 26 grudnia 2003 r., obowiązująca od dnia 1 maja 2004 r.; 最高人民法院关于审理人身损害赔偿案件适用法律若千问题的解 释: 2003 年,最高人民法院).

47 Z. Wang, K. Oliphant, Yangge Dance..., s. 36.

48 B.L. Leibman, Law in the Shadow..., s. 117, 118.

49 Z. Wang, K. Oliphant, Yangge Dance..., s. 36.

50 Ch. Xi, L. Yang, Medical liability laws in China: The tale of two regimes, „Tort Law Review” 2011, vol. 19(65), s. 68-70. 
mniemanie. W przeciwieństwie do odpowiedzialności cywilnej w reżimie administracyjnym ciężar dowodu spoczywał każdorazowo na powodzie ${ }^{51}$.

W razie ustalenia, że między powodem a pozwanym istniała relacja lekarz - pacjent, a ponadto powód doznał podczas leczenia uszczerbku na zdrowiu, pozwany powinien udowodnić, iż w trakcie czynności medycznych nie doszło do niedbalstwa lub jego postępowanie nie wywołało szkody u powoda. Takie rozwiązanie proceduralne umożliwia stronie powodowej łatwiejsze dochodzenie swojego roszczenia przed sądem, wymagając od pozwanego zachowania większej dbałości o prowadzenie i przechowywanie dokumentacji medycznej pacjenta. W toku postępowania sądowego instytucje medyczne często odmawiały pacjentom dostępu do ich własnej dokumentacji. W porównaniu z reżimem administracyjnym sądy mogą korzystać w szerszym zakresie z opinii ekspertów, które każdorazowo podlegały swobodnej ocenie dowodów ${ }^{52}$.

\section{Odpowiedzialność prawna za błąd w sztuce medycznej: reżim cywilny - ustawa z dnia 26 grudnia 2009 r. o odpowiedzialności deliktowej}

Uchwalenie w dniu 26 grudnia 2009 r. ustawy o odpowiedzialności deliktowej, która weszła w życie 1 lipca 2010 r., stanowiło ważną cezurę wyznaczającą moment zakończenia w ChRL systemu „podwójnej ścieżki”, czyli funkcjonowania dwóch reżimów prawnych dotyczących odpowiedzialności za szkody medyczne ${ }^{53}$. Ta kompleksowa regulacja prawna o deliktach miała wprowadzić ujednolicenie zasad przyznawania odszkodowań i zadośćuczynienia w sprawach deliktowych, w tym również w sprawach dotyczących błędu w sztuce medycznej ${ }^{54}$.

W rozdziale VII chińskiej ustawy z dnia 26 grudnia 2009 r. o odpowiedzialności deliktowej (dalej: u.o.d.) zawarto grupe przepisów regulujących podstawowe zasady odpowiedzialności za błąd w sztuce medycznej. Generalnie odpowiedzialność deliktowa za błąd w sztuce medycznej została oparta na zasadzie winy ${ }^{55}$. Ciężar udowodnienia winy instytucji medycznej (stronie pozwanej) spoczywa przede wszystkim na pacjencie (powodzie), zatem zostało to uregulowane odmiennie niz w poprzednio opisanych wytycznych NSL ${ }^{56}$. Zgodnie z art. 54 u.o.d. w sytuacji, gdy

\footnotetext{
51 Z. Wang, K. Oliphant, Yangge Dance..., s. 37.

52 Ch. Xi, L. Yang, Medical liability...

53 中华人民共和国侵权责任法, http://www.npc.gov.cn/wxzl/gongbao/2010-03/01/content_1580399.htm\#top (dostęp: 25.04.2020); R. McGivern Rossner, Medical Liability..., s. 19.

54 B.L. Leibman, Law in the Shadow..., s. 118, 119.

55 X. Zhao, The Duty of Medical..., s. 291.

56 Z. Wang, K. Oliphant, Yangge Dance..., s. 47.
} 
pacjent doznał jakiejkolwiek szkody podczas stawiania diagnozy i leczenia, a winę za to można przypisać instytucji medycznej lub członkowi jej personelu, obowiązek wypłaty odszkodowania i zadośćuczynienia ponosi instytucja medyczna. Wynika z tego, że odpowiedzialność za błąd w sztuce medycznej została całkowicie przypisana instytucjom medycznych, z wyłączeniem lekarzy i innych osób z personelu medycznego. Ratio legis jest zapewne skłonienie chińskich szpitali do wdrożenia właściwych standardów ochrony, pozwalających ograniczyć liczbę błędów w sztuce medycznej ${ }^{57}$. Z tego względu w interesie pacjentów jest wykazanie za pomocą dowodów wszystkich przesłanek odpowiedzialności deliktowej instytucji medycznej, obejmujących popełnienie deliktu, winę sprawcy, powstanie szkody, związek przyczynowy między deliktem a szkodą.

Błąd w sztuce medycznej jest kwalifikowany w chińskim ustawodawstwie jako delikt, którego popełnienie pociaga za sobą obowiązek naprawienia szkody, niezależnie od istnienia lub nieistnienia między stronami określonej umowy. W myśl art. 122 ustawy z dnia 15 marca 1999 r. - Prawo zobowiązań w sytuacji zbiegu podstaw odpowiedzialności kontraktowej i deliktowej, gdy zachowanie jednej strony zaszkodziło interesom osobistym lub majątkowym drugiej strony, strona poszkodowana ma prawo wybrać, na jakiej podstawie prawnej będzie dochodziła roszczen ${ }^{58}$. Odpowiedzialność kontraktowa z tytułu błędu w sztuce medycznej może być związana z niewykonaniem lub nienależytym wykonaniem zobowiązania przez lekarza lub instytucję medyczna. W przypadku odpowiedzialności kontraktowej istnienie takiego zobowiązania wynika z umowy zawartej z pacjentem, czyli tzw. umowy o świadczenie usług medycznych.

Artykuł 119 OZPC przewiduje: „Każdy, kto powoduje u innej osoby obrażenia fizyczne, powinien pokryć koszty leczenia i utratę dochodów za utratę czasu pracy, jak również koszty utrzymania, jeśli jest osobą niepełnosprawna; jeżeli poszkodowany zmarł, zobowiązany pokrywa koszty pogrzebu, niezbędne koszty utrzymania osób pozostających na utrzymaniu zmarłego oraz inne podobne wydatki”. Jeżeli dwie lub więcej osób wspólnie naruszy prawa innej osoby i wyrządzi jej szkodę, to ponoszą one odpowiedzialność wspólnie (art. 130 OZPC) ${ }^{59}$. Zasady odpowiedzialności kontraktowej maja jednak ograniczone zastosowanie w kontekście dochodzenia roszczeń z tytułu szkody medycznej, z uwagi na mniej korzystne - w porównaniu do odpowiedzialności deliktowej - rozwiązania dla poszkodowanych pacjentów. Zdaniem X. Zhanga decydują o tym następujące przesłanki:

57 J. Kearney, Why China's 2010..., s. 1073. Autor ten ocenia, że postawiona przez niego teza jest problematyczna ze względu na niedofinansowanie i przeludnienie szpitali w Chinach, przez co nie mogą inwestować środków finansowych we wdrożenie nowych standardów jakości.

58 Przepisy weszły w życie w dniu 1 października 1999 r. (中华人民共和国合同法); http:// www.gov.cn/banshi/2005-07/11/content_13695.htm (dostęp: 20.05.2020).

${ }^{59}$ Należy podkreślić, że nie jest to odpowiedzialność solidarna (joint and several liability), natomiast dwie lub więcej stron ponosi odpowiedzialność wspólnie ( joint liability). 
- odwrócenie ciężaru dowodu - zgodnie z zasadami odpowiedzialności deliktowej instytucje medyczne powinny udowodnić brak istnienia związku przyczynowego między zachowaniem lekarza a szkoda, jak również brak winy;

- brak w prawie zobowiazzań przepisów określających zasady dochodzenia roszczeń za szkodę medyczna:

- brak w prawie zobowiązań przepisów umożliwiających dochodzenie zadośćuczynienia za doznaną krzywdę;

- obowiązek zapewnienia opieki przez instytucję medyczną wynika w wielu przypadkach z przepisów ustawowych, których naruszenie wiąże się z odpowiedzialnością deliktową instytucji medycznej ${ }^{60}$.

Chińska ustawa Prawo zobowiązań nie zawiera przepisów regulujących zasady dochodzenia odszkodowania i zadośćuczynienia za błąd w sztuce medycznej. W praktyce jednak niedbalstwo lekarza będzie prowadziło do naruszenia praw lub dóbr osobistych pacjenta, np. prawa do życia, zdrowia czy integralności cielesnej ${ }^{61}$. Biorąc pod uwagę powyższe, można stwierdzić, że zasady odpowiedzialności publicznych i prywatnych instytucji medycznych są zasadniczo jednolite.

Odpowiedzialność oparta na zasadzie winy medycznej może być związana z naruszeniem obowiązków etyki medycznej (art. 55 u.o.d.), obowiązków wynikających z techniki medycznej (art. 57 u.o.d.) albo obowiązków dotyczących produktów medycznych (art. 59 u.o.d.). W myśl art. 55 u.o.d. personel medyczny, który zajmuje się diagnozą i leczeniem pacjenta, ma obowiazzek informować go o stanie zdrowia i podjętych środkach leczenia, ryzyku dotyczącym leczenia oraz uzyskać pisemna zgodę. Jeżeli nie można spełnić powyższego warunku, należy przekazać odpowiednie informacje i uzyskać pisemną zgodę od bliskiego krewnego pacjenta. W razie naruszenia obowiązku uzyskania świadomej zgody na leczenie i powstania szkody w obu powyższych przypadkach obowiązek wypłaty odszkodowania i zadośćuczynienia ponosi instytucja medyczna. Interpretując ów przepis literalnie, można stwierdzić, że niezachowanie przez lekarza wymogu świadomej zgody nie aktualizuje powstania obowiązku naprawienia szkody, jeśli w wyniku takiego zaniechania pacjent nie doznał żadnej szkody fizycznej lub psychicznej ${ }^{62}$.

Z kolei art. 57 u.o.d. stanowi, że jeśli ktokolwiek z członków personelu medycznego naruszył obowiązki dotyczące diagnozy i leczenia, odpowiadające standardom obowiązującym w czasie wykonania diagnozy i leczenia, to za wypłatę odszkodowania i zadośćuczynienia odpowiada instytucja medyczna ${ }^{63}$. Mimo pewnych rozbieżności terminologicznych Komisja Prawodawcza uznała, że „obowiązek diagnozy i leczenia, odpowiadającego obowiązującemu wówczas poziomowi medycznemu"

\footnotetext{
${ }^{60}$ Por. X. Zhang, Legislation of Tort Liability Law in China, Beijing 2018, s. 303, 304.

${ }^{61}$ Ibidem.

62 Z. Wang, K. Oliphant, Yangge Dance..., s. 45.

63 X. Zhao, Chinese Medical Negligence Law..., s. 416.
} 
można traktować tak samo jak „obowiązek opieki” ${ }^{64}$. Wyrażenie to nie zostało wyjaśnione w innych przepisach, w związku z czym jego treść musi zostać doprecyzowana w orzecznictwie ${ }^{65}$. Pojęcie poziomu medycznego, do którego z kolei nawiązano w art. 57 i 60 ustawy, zostało zaczerpnięte przez chińskiego ustawodawcę z japońskiego systemu prawnego ${ }^{66}$.

Jak stanowi art. 59 u.o.d., pacjent ma prawo wystapić o odszkodowanie i zadośćuczynienie od producenta, dostawcy krwi do transfuzji lub instytucji medycznej wówczas, gdy szkoda pacjenta została spowodowana wadą jakiegokolwiek leku, środka dezynfekującego, instrumentu medycznego lub niezgodnej z normami transfuzji krwi. Jeżeli pacjent zażądał odszkodowania i zadośćuczynienia od instytucji medycznej z tytułu odpowiedzialności za produkt medyczny, instytucja medyczna, która wypłaciła stosowną kwotę, ma roszczenie regresowe w stosunku do właściwego producenta lub instytucji. Chińskie szpitale odgrywają ważną rolę jako dostawcy produktów medycznych, czerpiąc znaczną część zysków ze sprzedaży leków. Szacuje się, że pochodzi z niej ok. 50\% przychodów większości szpitali w kraju, przy czym większy udział sprzedaży leków w ogólnej puli przychodów maja szpitale prywatne ${ }^{67}$.

W niektórych przypadkach ustawodawca wyraźnie wskazał okoliczności, w jakich domniemywa się istnienie winy po stronie instytucji medycznej. Zgodnie z art. 58 u.o.d. należy przyjąć, że instytucja medyczna ponosi winę tylko wtedy, kiedy szkoda pacjenta miała miejsce wskutek: naruszenia przepisów ustawowych, administracyjnych lub przepisów dotyczących procedur oraz standardów w zakresie diagnozowania i leczenia; ukrywania lub odmowy udostępnienia danych o historii choroby związanej ze sporem; fałszowania, modyfikowania lub niszczenia jakichkolwiek danych o historii choroby. Powyższa konstrukcja prawna (tzw. res ipsa loquitur) z jednej strony ułatwia powodowi dochodzenie roszczeń majątkowych, gdyż nie musi przedstawiać dowodów winy, jeżeli instytucja medyczna naruszyła przepisy lub procedury medyczne albo nie udostępniła dokumentacji medycznej. Z drugiej strony utożsamianie każdorazowo obejścia przepisów lub standardów medycznych jako błędu w sztuce medycznej może być nieadekwatne do okoliczności, prowadząc do petryfikacji praktyki lekarskiej, dlatego adekwatne jest bardziej elastyczne podejście.

Instytucja medyczna nie ponosi odpowiedzialności za błąd w sztuce medycznej, gdy: pacjent lub jego bliski krewny nie współpracuje z instytucją medyczną w zakresie diagnozy i leczenia zgodnie z procedurami oraz standardami diagnozy

${ }^{64}$ Ibidem. W drugim projekcie ustawy o odpowiedzialności deliktowej projektodawcy posłużyli się pojęciem „obowiązek opieki”, które następnie zastąpiono pojęciem „obowiązek diagnozy i leczenia”, to drugie wyrażenie zostało zachowane w treści uchwalonej ustawy z $2009 \mathrm{r}$.

65 Z. Wang, K. Oliphant, Yangge Dance..., s. 45, 46.

${ }^{66}$ X. Zhao, The Duty of Medical..., s. 294.

67 Z. Wang, K. Oliphant, Yangge Dance..., s. 46. 
i leczenia; personel medyczny dopełnił obowiązku racjonalnej diagnozy i leczenia w sprawie nagłych przypadków, takich jak ratowanie pacjenta w stanie krytycznym; diagnoza i leczenie pacjenta sa trudne $z$ uwagi na poziom medycyny w tym czasie (art. 60 u.o.d.). Chiński ustawodawca wyraźnie wymienił tutaj przypadki, gdy instytucja medyczna nie może wypełnić obowiązku naprawienia szkody, czyli okoliczności związane z brakiem winy po jej stronie, jeśli w czasie udzielania pacjentowi pomocy działała zgodnie z zasadami sztuki medycznej.

Wprowadzenie zmian legislacyjnych miało z pewnością wpływ na krajową praktykę orzeczniczą. W latach 2007-2014 liczba postępowań sądowych dotyczących błędów w sztuce medycznej w ChRL wzrosła o 81,3\%. W 2014 r. sądy krajowe rozpatrywały łącznie prawie 20 tys. takich spraw, spośród których najwięcej sporów medycznych zakończono na drodze mediacji $(41,8 \%)$, w podobnej liczbie spraw rozstrzygnięto spór przed sądem (39,42\%), w innych przypadkach powództwo oddalono lub odrzucono $(15,78 \%)^{68}$. Dzięki nowym rozwiązaniom prawnym coraz więcej osób poszkodowanych uświadamia sobie możliwość skutecznego dochodzenia przed sądem roszczeń za szkody medyczne. W tych okolicznościach oczekuje się wydania przez NSL interpretacji przepisów prawa cywilnego w zakresie błędów w sztuce medycznej.

W 2014 r. ogłoszono dokument, w którym określono możliwe kierunki orzecznictwa NSL, mogące stać się podstawą wykładni przepisów o deliktach. Po pierwsze, osoba, która chce wnieść powództwo w sprawie o błąd w sztuce medycznej, powinna udowodnić, że korzystała jako pacjent z pomocy medycznej w określonej instytucji medycznej (istnienie relacji lekarz - pacjent). Po drugie, instytucja medyczna powinna przedstawić dowody, które potwierdza, że nie jest odpowiedzialna za szkodę z uwagi na istniejące okoliczności, np. podjęcie przez personel medyczny wszelkich niezbędnych czynności lub aktualny stan rozwoju wiedzy naukowej. Po trzecie, w sprawach spornych, gdy jedna strona podejrzewa, że dokumentacja medyczna została podrobiona, przerobiona, ukryta, przez co nie jest możliwe ustalenie związku przyczynowego i rozmiaru szkody, strona za to odpowiedzialna ponosi negatywne konsekwencje w postępowaniu sądowym ${ }^{69}$.

Dalszym krokiem w zakresie zapobiegania sporom medycznym i właściwego ich rozwiązywania, jak również poprawienia ochrony interesów personelu medycznego i pacjentów było przyjęcie przez Radę Państwa ChRL dekretu nr 701 Przepisy w sprawie zapobiegania i rozstrzygania sporów medycznych z dnia 20 czerwca 2018 r., które weszły w życie 1 października 2018 r. ${ }^{70}$ Powyższa regulacja stanowi

68 Dane Chińskiego Forum na temat praworządności w Pekinie pochodzą ze strony: http:// www.jkb.com.cn/news/industryNews/2015/0421/367100.html (dostęp: 20.05.2020).

69 Opinia ws. surowego karania czynów niezgodnych z prawem i przestępstw dotyczących systemu medycznego oraz zachowania prawidłowych warunków służby zdrowia z 2014 r.; https://supremepeoplescourtmonitor.com/tag/medical-malpractice-cases/ (dostęp: 20.05.2020). 70 医疗纠纷预防和处理条例. 
jasny sygnał, że państwo chińskie kontynuuje pogłębioną politykę dotyczącą zarządzania jakością i bezpieczeństwem medycznym, reformy systemu opieki medycznej, zapobiegania sporom medycznym itp. Jak wskazano w art. 2 Przepisów, mają one zastosowanie do sporów medycznych rozumianych jako spory między personelem medycznym a pacjentami związane z czynnościami diagnozowania i leczenia. Jeżeli doszło do sporu medycznego, obie zainteresowane strony moga: podjać dobrowolne negocjacje, wystapić $z$ wnioskiem o mediację albo ugodę administracyjną, złożyć pozew do sądu, skorzystać z innych sposobów rozwiązania sporu określonych w przepisach ustawowych i wykonawczych (art. 22 Przepisów).

\section{Podsumowanie}

W okresie rządów Kuomintangu chiński system prawny został ukształtowany według wzorców zachodnich, jednak po wprowadzeniu w Chinach rządów komunistycznych w 1949 r. nastapiło odejście od poprzednich rozwiązań w kierunku ideologizacji prawa w duchu marksizmu-leninizmu. Po proklamowaniu ChRL przez bardzo długi czas odpowiedzialność za błąd w sztuce medycznej nie była uregulowana w żadnych przepisach, a wszelkie decyzje mogły być podejmowane nieformalnie na odpowiednim szczeblu partyjnym. Zapoczątkowanie reform Denga Xiaopinga spowodowało zmianę struktury służby zdrowia, gdyż od tej pory coraz większą rolę w zakresie świadczenia usług medycznych odgrywał sektor prywatny. Interesujące jest rozwinięcie się w Chinach dwóch niezależnych systemów odpowiedzialności za błąd w sztuce medycznej - cywilnego i administracyjnego, pozwalajacych dochodzić przez pacjentów roszczeń za uchybienia spowodowane wadliwymi czynnościami medycznymi. Odpowiedzialność deliktowa była bardziej zorientowana na ochronę praw i interesów pacjenta, natomiast odpowiedzialność administracyjna miała raczej służyć interesom instytucji medycznych. System podwójnej ścieżki został zasadniczo zreformowany w ChRL dopiero w ostatnich latach wraz z uchwaleniem ustawy z dnia 26 grudnia 2009 r. o odpowiedzialności deliktowej.

\section{SUMMARY}

\section{THE LIABILITY FOR MEDICAL MALPRACTICE IN THE LEGAL SYSTEM OF THE PEOPLE'S REPUBLIC OF CHINA}

The liability for medical malpractice in the legal system of the People's Republic of China was shaped in the $20^{\text {th }}$ and early $21^{\text {st }}$ centuries. During the period of Mao Zedong's government, there was a conviction that national legislation should be instrument for achieving ad 
hoc political goals, all decisions were made informally, on a party basis. Patients did not have the possibility to claim compensation for injury resulting from medical malpractice. A fundamental change took place after Deng Xiaoping came to power as part of the reform and "opening up to the world", patients ceased to be treated as beneficiaries of social assistance, and became all consumers of health services. Initially, persons injured as a result of medical malpractice may claim compensation through administrative proceedings, which does not provide compensation claim to the amount of injury actually suffered. The "double path" system, which consists of two independent legal regimes - civil and administrative - has evolved significantly over time. The Tort Liability Law of the People's Republic of China enacted in 2009 includes comprehensive legal solutions for medical malpractice in China. 